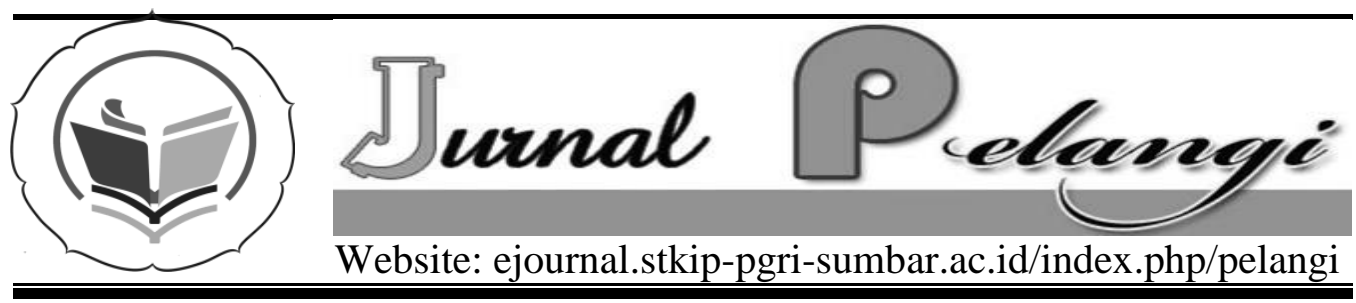

\title{
ANALISIS KEBUTUHAN TERHADAP PENGEMBANGAN INSTRUMEN PENILAIAN OTENTIK
}

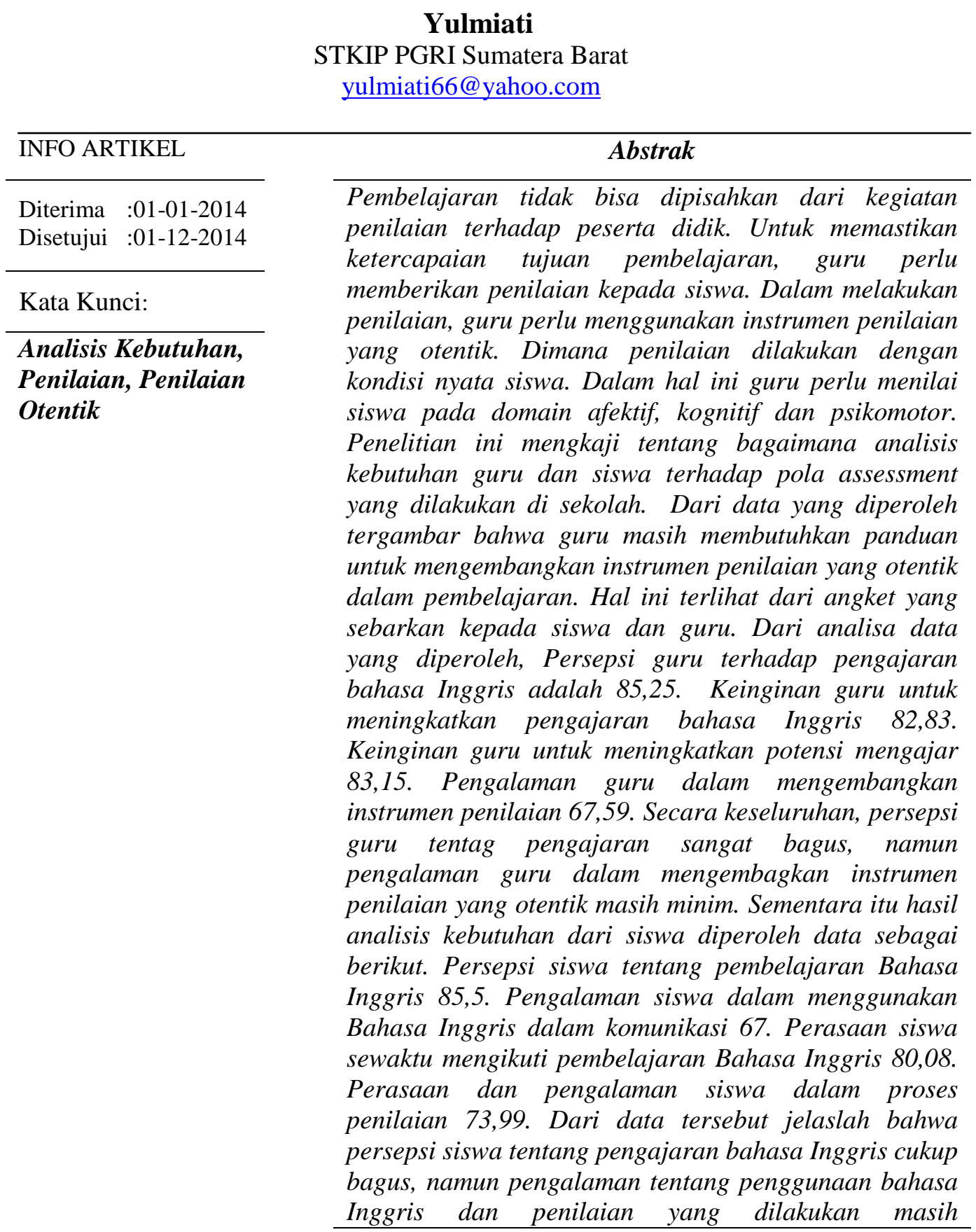


dikategorikan masih rendah. Melihat hasil dari analisis kebutuhan guru dan siswa tersebut, perlu adanya studi tentang pengembangkan instrument penilaian yang otentik berdasarkan teori dan praktis sehingga bisa digunakan oleh guru di sekolah dalam proses pembelajaran.

Keywords:

Need Analysis, Assesment, Authentic Assesment
Dibuatnya kurikulum 2013

bertujuan untuk melaukan pembaharuan dalam pendidikan. Pembaharuan tersebut tentu akan terkait dengan pembaharuan pada

\section{PENDAHULUAN}

\section{melaukan} kan da
Learning is always related to the assessment of the learners. To ensure the achievement of the learning objectives, teachers need to provide an assessment to the students. In assessing the students, the teachers need to use an authentic assessment instrument in which it is based on the student's real condition. On this case, the teacher needs to assess the students affectively, cognitively and psychomotorically. This research studies about how the need analysis of the teachers and students to the assessment pattern used on the school. The data shows that the teachers still need a guide to develop an authentic assessment instruments in learning. It is found out from the questionnaire spread to students and teachers. From the data analysis, perception of teachers to the teaching of English is 85.25. The teacher's need to improve the teaching of English is 82.83. The teacher's need to improve the teaching potential is 83.15. Teacher experience in developing assessment instruments is 67.59. Overall, the perception of the teacher's teaching is good, but the experience of teachers in developing the authentic assessment instruments is still low. Meanwhile, the results of the need analysis of the students are perceptions of students about learning English i.e.85.5. Student's experience in using English in communication is 67. Feeling of students in following the English Learning is 80.08. Feelings and experiences of students in the assessment process are 73.99. From these data it is clear that students' perceptions about teaching English is good enough, but the experience of using English and assessments carried out is still considered low. Looking at the results of the need analysis of teachers and students, the need for the study of developing an authentic assessment instrument, based on the theory and practical, can be used by teachers in the learning process of the school.

\section{pengajaran, dengan segala} perangkatnya, termasuk juga penilaian. Pada kurikulum 2013, guru diharapkan melakukan penilaian dengan instrumen penilaian yang otentik. Sementara itu, 
penilaian otentik masih baru bagi guru, apalagi saat guru perlu mengembangkan instrumen penilaian tersebut untuk menerapkan penilaian otentik di dalam kelas. Untuk melihat kebutuhan guru terhadap perlunya mengetahui cara mengembangkan instrumen penilaian otentik, tentu perlu analisis kebutuhan terhadap hal terebut. Sehingga bisa dilakukan langkah selanjutnya unuk membantu guru dalam mengembangkan instrumen penilaian.

Penilaian otentik merupakan penilaian alternatif bagi guru dalam menilaian kemampuan siswa dalam pembelajaran.Kalau selama ini, penilaian terhdap siswa lebih dititik beratkan pada ranah kognitif.Pada penilaian otentik, ranah afektif dan ranah psikomotor perlu juga jadi pertimbangan dalam menilai siswa.

Analisis kebutuhan perlu dilakukan.Dari analisis ini, bisa diketahui harapan-harapan guru dalam pelaksanakan pembelajaran. Selain itu, akan didapat juga gambaran bagaiaman pelaksanaan pembelajaran selama ini. Dengan demikian, hasil dari analisis kebutuhn ini diharapkan bisa menjadi pertimbangan untuk mengembangkan instrumen penilaian yang otentik di sekolah.

Dalam proses pembelajaran perlu dilakukan penilaian. Dari penilaian tersebut, guru bisa mendapatkan gambaran apakah siswa paham dengan materi ajar atau
tidak.Ada beberapa konsep tentang penilaian dari beberapa ahli.

M. David Miller dkk. Menyatakan bahwa assessment terhadap pembelajaran siswa membutuhkan teknik tertentu di dalam mengukur prestasi belajar siswa. Lebih lanjut, mereka juga berpendapat bahwa assessment lebih dari sekedar kumpulan beberapa teknik, melainkan proses sistematis yang memainkan peran penting dalam pengajaran efektif (2009). Assessment dimulai dari identifikasi tujuan pembelajaran, dan memonitor proses yang dilakukan siswa untuk mencapai tujuannya, dan berakhir dengan penilaian yang berkaitan dengan sejauh mana tujuan di atas telah tercapai.

Lebih jauh lagi, David W. Johnson dan Roger T. Johnson menyatakan bahwa assessment mencakup upaya mengumpulkan informasi mengenai kualitas atau kuantitas peningkatan yang dibuat oleh seorang siswa, sebuah kelompok, kelas, sekolah, guru, atau seorang administrator (2002:2).Dari penilaian inilah guru diharapkan bisa mengukur kemampuan siswa tentang pemahaman mereka terhadap pelajaran yang sudah didapatkan.

Menurut Brown (2004), penilaian adalah proses berkelanjutan yang dilakukan guru secara tidak sadar dalam menilai unjuk kerja siswa, dimana siswa memberikan respon terhadap pertanyaan yang diberikan guru, memberikan 
komentar atau mencobakan kosa kata baru. Jadi dalam penilaian bahasa, setiap aktifitas siswa yang menunjukkan kemampuannya dalam merespon guru dikategorikan sebagai penilaian.

Berdasarkan pedoman penilaian dari Depdiknas (2003), penilaian otentik adalah proses pengumpulan informasi oleh guru tentang perkembangan dan pencapaian pembelajaran yang dilakukan anak didik melalui berbagai teknik yang mampu mengungkapkan, membuktikan, atau menunjukkan secara tepat bahwa tujuan pembelajaran dan kemampuan (kompetensi) telah benar-benar dikuasai dan dicapai.

Sementara itu Pucket dan Black dalam Arikunto (2012) menyatakan bahwa Penilaian Otentik adalah penilaian terarah pada semua kejadian yang terdapat pada diri siswa dan lingkungannya secara riil. Berarti guru menilai siswa dengan melihat aktifitas dan kemampuan siswa yang dilakukan secara nyata.

Oleh karena yang diraih adalah hasil seutuhnya yang ada pada peserta didik, maka bukan hanya penilaian ranah kognitif seperti yang biasa dilakukan guru dengan soalsoal tertulis saja, tetapi juga melalui afektif dan psikomotor.Jadi hsil yang didapatkan pun informasi tentang kompetensi belajar siswa secara utuh.

Berdasarkan ketentuan yang diberlakukan oleh Departemen
Pendidikan Nasional, melalui Pusat Penilaian Pendidikan, menjelaskan bahwa beberapa teknik penilaian bisa dilakukan oleh guru bahasa Inggris.Teknik-teknik tersebut disesuaikan dengan dimensi penilaian yang perlu dilakukan secara berimbang.Adapun dimensi penilaian yang otentik tersebut adalah ranah afektif, kognitif, dan psikomotor siswa yang dikaitkan dengan materi/tujuan pembelajaran yang hendak dicapai.

Menurut Kunandar (2013:99), ranah afektif pada penilaian merupakan perasaan yang dimiliki oleh seseorang atau penilaiannya terhadap suatu objek. Perasaan dan penilaian ini tentu saja dipengaruhi oleh pengetahuan seseorang terhadap suatu objek tersebut.Pengetahuan itulah yang mendasarinya untuk menilai objek tersebut.

Sementara itu, Kunandar (2013: 159) memandang bahwa penilaian kognitif yaitu penilaian yang dilakukan guru untuk mengukur tingkat pencapaian atau penguasaan peserta didik dalam aspek pengetahuan yang meliputi ingatan atau hafalan, pemahaman, penerapan atau aplikasi, analisis, sintesis dan evaluasi.Berarti aspek pengetahuan tersebut menunjukkan tingkatan pengetahuan yang dimiliki oleh siswa terhadap materi pelajaran tertentu.

Selanjutnya, Kunandar (2013) menyatakan bahwa ranah 
psikomotor adalah ranah yang berkaitan dengan ketrampilan (skill) atau kemampuan bertindak setelah seseorang menerima pengalaman belajar tertentu.Kunandar juga menambahkan bahwa ranah psikomotor sebenarnya kelanjutan dari hasil belajar kognitif dan afektif.Artinya, hasil belajar kognitif dan afektif menjadi hasil belajar psikomotorik apabila peserta didik telah menunjukkan prilaku atau perbuatan tertentu.

Untuk mengetahui kebutuhan siswa terhadap penilaian otentik, disebarkan angket ke beberapa sekolah, diantaranya SMA 1, SMA 4, SMA 5, dan SMA Adabiah. Angket dibuat dua jenis, yaitu angket guru dan angket untuk siswa.Dari angket tersebut peneliti mendapatkan informasi tentang perasaan dan opini guru dan siswa tentang penilaian yang dilakukan selama ini.Dari hasil angket itulah peneliti memperoleh analisis kebutuhan guru dan siswa terhadap penilaian yang otentik.

a. Analisis Kebutuhan dari Guru

Peneliti melakukan beberapa aktivitas untuk melakukan analisis kebutuhan dari guru. Angket didistribusikan kepada 23 orang guru, sebagai representasi dari guru SMA Negeri dan Swasta di kota Padang. Dari hasil angket, peneliti bisa mendapatkan gambaran umum tentang opini, sikap dan pengalaman guru dalam melaksanakan penilaian di sekolah.

Sesudah guru mengisi angket, peneliti menganalisis data.Adapun hasil analisis data, bisa dilihat di tabel 1 berikut ini.

Tabel 1. Hasil Analisis Kebutuhan dari Guru

\begin{tabular}{|c|l|c|}
\hline No & \multicolumn{1}{|c|}{ Indikator } & Skor \\
\hline 1 & Persepsi guru teradap pengajaran bahasa Inggris & 85,25 \\
\hline 2 & Keinginan guru untuk meningkatkan pengajaran bahasa Inggris & 82,83 \\
\hline 3 & Keinginan guru untuk meningkatkan potensi mengajar & 83,15 \\
\hline 4 & Pengalaman guru dalam mengembangan instrument penilaian & 67,59 \\
\hline
\end{tabular}

Dari hasil analisis kebutuhan guru, bisa disimpulkan bahwa persepsi dan keinginan guru untuk meningkatkan potensi dalam pengajaran sangat baik. Artinya, guru mempunyai pandangan yang positif untuk meningkatkan proses pembelajaran. Akan tetapi, mengenai pengalaman guru dalam mengembangkan instrument penilaian yang otentik masih menunjukkan skor yang masih rendah. Hal ini bisa jadi disebabkan bahwa guru masih mempunyai pengalaman yang terbatas dalam mengembangkan instrument penilaian.

b. Analisi kebutuhan dari siswa

Peneliti juga menyebarkan angket kepada 107 orang siswa SMA di kota Padang. Dari angket tersebut bisa diketahui persepsi, perasaan, mereka 
terhadap pembelajaran dan penilaian bahasa Inggris.Hasil angket tersebut dianalisis, hasilnya bisa dilihat di tabel 2 berikut ini.

Tabel 2: Analisis Kebutuhan dari Siswa

\begin{tabular}{|c|l|c|}
\hline No & \multicolumn{1}{|c|}{ Indikator } & Hasil \\
\hline 1 & Persepsi siswa tentang pembelajaran Bahasa Inggris & 85,5 \\
\hline 2 & $\begin{array}{l}\text { Pengalaman siswa dalam menggunakan Bahasa Inggris } \\
\text { dalam komunikasi }\end{array}$ & 67,0 \\
\hline 3 & $\begin{array}{l}\text { Perasaan siswa sewaktu megikuti pembelajaran Bahasa } \\
\text { Inggris }\end{array}$ & 80,08 \\
\hline 4 & Perasaan dan pengalaman siswa dalam proses penilaian & 73,99 \\
\hline
\end{tabular}

Dari analisa data di atas, bisa disimpulkan bahwa persepsi sisiwa tentang pembelajaran bahasa Inggris sudah bagus.Mereka beranggapan bahasa Inggris bermanfaat bagi mereka.Mereka juga memilki perasaan yang positif terhadap pembelajaran bahasa Inggris. Artinya mereka menikmati pelajaran bahasa Inggris.Akan tetapi, siswa masih mempunyai masalah dalam penggunaan bahasa Inggris dalam komunikasi.Ini mengindikasikan bahwa masih sulit bagi mereka untuk mempraktekkan bahasa Inggris dalam kehidupan sehari-hari. Sementara itu, perasaan dan pengalaman mereka dalam proses penilaian juga menunjukkan skor yang masih rendah.

Dari hasil analisis kebutuhan, peneliti memperoleh gambaran umum tentang pegetahuan guru dan persepsi siswa tentang penilaian. Data ini juga membantu peneliti untuk memperoleh pertimbangan dalam mengembangkan instrument penilaian yang otentik berdasarkan teori dan praktis yang jarang digunakan oleh guru di sekolah dalam proses pembelajaran.

\section{KESIMPULAN}

Dari hasil analisis kebutuhan, peneliti memperoleh gambaran umum tentang pegetahuan guru dan persepsi siswa tentang penilaian. Mereka masih butuh pengetahuan dan pengalaman dalam melaksanakan penilaian otentik dalam pembelajaran.Perlu bagi guru untuk memperkaya khazanah pengetahuannya untuk mengembangkan instrumen penilaian yang otentik. Data ini juga menjadi pertimbangan bagi peneliti untuk mengembangkan instrumen penilaian yang otentik berdasarkan teori dan praktis.

\section{UCAPAN TERIMAKASIH}

Terbitnya tulisan ini tidak terlepas dari bantuan berbagai pihak, untuk itu penulis ucapkan terima kasih yang sebesar-basarnya kepada Pihak STKIP PGRI Sumatera Barat khususnya pengelola jurnal Pelangi yang telah memberikan kesempatan kepada penulis untuk menulis 
dijurnal Pelangi.Selanjutnya penulis juga berterima kasih kepada para penyumbang sumber insirasi yang telah memerikan inspirasi bagi penulis untuk mengutip atau menggunakan tulisannya sebagai bahan referensi.

\section{DAFTAR PUSTAKA}

Arikunto, Suharsini. 2012. DasarDasar Evaluasi Pendidikan. Edisi ke-2. Jakarta: PT. Bumi Aksara.

Brown, H. Douglas. 2004. Language Assessment: Principles and Classroom Practices. New York: Pearson Education.

Depdinas. 2003. Penilaian Tingkat Kelas: Pedoman Bagi Guru SD/MI, SMP/MTs, SMA/MA, dan SMK. Jakarta; Pusat Penilaian Pendidikan - Badan Penelitian dan Pengembangan Departemen Pendidikan Nasional.

Johnson, David W. and Roger T. Johnson. 2002. Meaningful Assessment: A Manageable and Cooperative Process. Boston: Allyn and Bacon.

Kunandar. 2013. Penilaian Autentik (Penilaian Hasil Belajar Peserta Didik Berdasarkan Kurikulum 2013). Jakarta: Rajawali Pers. 